\title{
The Improvement of Professional Competences of Culture-Based Vocational Education Teacher
}

\author{
Y. Mulyadi \\ Department of Electrical Engineering Education \\ Universitas Pendidikan Indonesia \\ Bandung, Indonesia \\ yadi6365@gmail.com
}

\begin{abstract}
The improvement of professional vocational education teachers in the context of lifelong education is a series of comprehensive systems that are continuously performed, both formally and informally. Life experience is the structure of teachers built on the perfect combination of cultural process of verbal skills, mastery of teaching materials and professional teacher's mastery of learning methods. The process of professional competences improvement is not a natural process that is routine, traditional and running independently. Instead, it is a process that requires strategic, clear, and actual planning in a structured system in order to achieve better education. In fact, dichotomous debate occurs with pros and cons, either professional competences improvement is a savior god in improving the quality of education, and on the other hand, criticism is also emerging. In general, the process of professional competences improvement is a fragmented activity, a coherent meeting that is decontextualized and isolated from real classroom situation. The approaches to know the professional competences improvement of vocational education teacher can be conducted with various patterns and models. This research aims to know the profile improvement of professional vocational education teachers who have knowledge of the culture. The method which is used is survey by descriptive research approach. The population of this research is vocational education teachers with expertise in the field of electric power which have possessed certification at SMKN (Vocational Education) in West Java. The finding of research shows that the improvement of professional vocational teacher's competences has not become an integral structure in the constellation of continuous professional development and the commitment on the improvement of professional vocational teacher's competences that include academic, personality, ethnopedagogy, and self-efficacy competence should be developed in the context of local cultural substance strength.
\end{abstract}

Keywords- Continous Professional Development (CPD); teacher's competences; ethno-pedagogy; self-efficacy.

\section{INTRODUCTION}

Technology and vocational education is the oldest from of education born along with the history of human civilization itself. When people formed a society, they began a process of social culture that gave rise to new paradigms of people's lives, including the improvement of the standard of living, selfdefense, mastery and domination of other groups, wars and technological inventions that became the forerunners of the industrial revolution. These new paradigms gave birth to the creativity and various creations with the approaches of skill and vocations. The efforts to improve the living standards caused people to possess the abilities to hunt, build houses, farm etc. War among tribal groups triggered the attempt to defend themselves and gave strong influence on the creativity in making weapons and other equipment. Meanwhile technological inventions increased people's ability to work more efficient and productive. The big question is: are the phenomena above the forerunners of technology and vocational education? Is vocational education a cultural process? Are the basic characteristics of local culture can contribute to vocational education? Can the development of culture-minded professional vocational teachers improve the quality of vocational education? To answer these questions, this paper will theoretically and empirically examine the fundamental issues of the development of culture-minded professional vocational teachers.

Technology and vocational education is an integral part of people's daily lives, so that in the past there was a process of passing down the expertise and skills from generation to generation. The parents who were builders caused their children to work in that field of expertise, the parents who were farmers caused their children to have the skills to cultivate farming fields, and the parents who were hunters caused their children to have the courage to make a living in the forest. Empirical evidences show that the process of education is a process of people's culture in the past. When the development of the people's culture and needs became higher, people began the process of developing a broader life, cross-territorial life, higher satisfaction and achievements. Working demands became increasingly complex, people began to form their own communities with self-determined standards. Competitions started to happen on a large scale, and there are roles of internal and external parties in working together to produce education with better quality [1].

\section{A. Improvment of Culture-Minded Vocational Teachers}

In the modern era, vocational education experienced sharp changes, both on its scientific substance, working orientation and learning model. Developed countries develop their own revolutionary models, with various approaches, which have become guides for many developing countries. The success and 
failure of the models of vocational education is one of the factors influencing economic growth and industrialization. The failure of vocational education is characterized by unemployment rate of productive labor force, low economic growth and decline of people's purchasing power, high inflation rate as well as faltered non-formal economy. Therefore, the development of vocational education started to be re-developed on the aspect of employment orientation and cultural dimensions of each country.

Professional education of teachers becomes the first option of vocational education infrastructure improvements that are very complex. Continuous professional education development is a strategic effort in preparing professional teachers and should become one of the important instruments in conducting the reformation of teachers' mind set. Substantial updates in the mastery of knowledge and improvements in instructional learning in the classroom [2]. Professional development of teachers is developed in line with people's movement and cultural changes occurring locally, nationally and regionally. Therefore the educational process is one of basic solutions for people in facing new challenges. Education becomes an important instrument in improving the ability to survive and adapt to the existing environment. People's education and culture can't be separated diametrically, because the two are a unity in human life.

Critical view states that education always lags behind the development of people's culture due to the school system with traditional patterns and approaches. Education experiences many serious problems in adjusting to the changes in life that happened very quickly in the last century. Therefore a long educational process that is mobile and is conducted continuously and simultaneously is needed. Education should be conducted longitudinally and in 'time series' throughout life by promoting flexibility and massive innovation. This situation has led to substantial changes in professionalism, competency and skills needed by individuals in the development of society. It is important for individuals to re-check their professional development and the acquisition of new knowledge through different processes than those with which we have been familiar from long ago until now [3].

The substance of cultural-minded education is a construction of creative spiritual force in the life of a nation. A professional teacher is demanded to conduct massive expansion to deepen the field of local, national and regional ethno-pedagogical knowledge. The characteristics of traditional culture, combined with universal values form the first step in developing the basic ideas and attitudes towards cultural heritage. Possessing great practical importance, pedagogy allows us to adapt to modern educational and training techniques with specific characteristics of traditional culture, as well as to maintain and use valuable ideas, methods and forms of traditional education. The formation and development of ethno-pedagogy as a science have its own special features related to culture and tradition. Therefore, ethno-pedagogical education allows us to prepare future teachers who work to revive, strengthen and preserve the popular progressive pedagogical tradition and the knowledge obtained in their professional activities.
Vocational education is more oriented to the working word and industrial world, which, on the other side, move with high acceleration and are always in a state of strong, 'transient' culture. Rapid technological developments in all sectors of life make lifelong vocational education an urgent need. Continuous education causes all the components to be responsive, dynamic and able to adapt better to the real world demands in the industry. These developments, including rapid technological developments in electrical engineering, require the concept of lifelong learning in their practice. Industrial needs and future perspectives are limitless [4].

Continuous professional development of vocational teachers in the context of lifelong education is a comprehensive life experience that is continuously done both formally and informally. Life experience of teachers is a perfect combination structure built of a long process of verbal skills, mastery of teaching materials and mastery of learning methods [5]. The process of continuous professional development is not a natural process that is routine, traditional and running independently. Instead, it consists of a process that requires strategic, clear and actual planning in a structured system in order to achieve better education. In fact, debates occur dichotomously with the pros and the cons. On one hand the continuous professional development is a savior god to improve in the quality of education, but on the other hand, criticism is also emerging. Generally, the process of continuous professional development is a fragmented activity, a coherent meeting that is 'decontextualised' and isolated from real classroom situation [6].

Vocational teachers' professionalism is conceptually aware about the fact that increased knowledge, insight and cultural dynamics are important parts separated from duties and responsibilities. Besides, the profession of vocational teacher is a collective profession with a very large number of communities, thus requiring strong cooperation and collaboration with each other. This approach provides the opportunity for teachers to build a collegial and professional dialogue among teachers. Certainly, educational institutions also have a huge stake in realizing the vision, mission and activity programs, thus requiring new skills that should be possessed by the teachers. Therefore, these three patterns constitute fundamental approach that became the archetype of continuous culture-minded professional development.

The substance of continuous professional development should have the following basic characteristics: (a) It is based on the concept of constructivism, not just a transmission [7]. (b) It is built within long-term framework [7]. (c) It is close to the reform of educational performance [8]. (d) It is capable of self-reflection [9]. The characteristics of continuous professional development for vocational teachers will give new color on the processes related to a series of increased knowledge and new experiences. The construction of development of professional teachers is the construction of cultural community, in other words the development of teachers based on the culture existing in the society itself. 


\section{B. Factors influencing the improvement of teacher's professional competences}

Many factors affect the professional competences of culture-minded vocational teachers, but in this paper, only four exogenous variables were observed. The first variable related to the substance of the commitment of improvement of academic competence and skills is a portrayal of the efforts done by professional vocational teachers to improve the scientific competence, both in theoretical concepts and practical aspects of skills and industrial capability. Extensive individual experience as vocational teachers and working experience in the industry are partial sections that become important components in improving the professional capabilities [10]. In a competency-based education, there is a gradual and systematic paradigm shift that thinks in the specific task qualification towards a more general competence [11]. Basic and general knowledge become important in the structure of vocational education. This new paradigm is changing the scientific fundamental structure in the 1970s and 1980s, with the concept of competency-based education in the form of the detailed and narrow formulation and particular task performance criteria was determined specifically [12] and the importance of how to apply the knowledge in various work situation was ignored [13].

The changes of competence paradigm during the last two decades occurred in several countries, such as Germany, France and Austria. The changes occurring focused on the more comprehensive development and approach to competency-based education in a learning situation integrated with knowledge, skills, and attitudes. Viewed from scientific development, vocational education, which was originally limited and specific in nature, later changed to be more universal and general. The main elements of vocational education become increasingly common, or theoretical. The boundary between academic education and vocational education has become increasingly blurred [1]. Whereas in the development of competency-based education, learners are faced with various core issues that they face in their professional lives by developing the portable competencies from one context to another [14].

The second factor is related to the commitment of learning competences which is the main instrument in students' learning development in all units, either in the classroom, laboratory, workshop, studio or workshop. Certified vocational professional teachers must possess competences and work with high level of professional performance. Professional vocational technology education teachers must possess independence, strong motivational encouragement in working, including the mastery of the rules of professional vocational education in refining their teaching competence [15]. In performing professional works, vocational technology education teachers must have competences in designing learning that is laden with administration experience for the learners. Besides, the ability of the learning planning is based on the mastery of the pedagogical rules and curriculum structure [16].

The third factor that is highly urgent is the commitment of personality competence of professional vocational school teachers. Teacher as a person has the characteristics of a work ethic, personal commitment, integrity, nationalism, and communal fanaticism which have a major impact on the level of professionalism of vocational teachers. The perspective debate about teachers' personality is still dichotomous, with one side argued that good teachers are born, while the other side claimed that ideal teachers must be formed through a long developmental process. The best compromise regarding teachers' personalities that qualify ideal requirements is that teachers must have talents, which are subsequently developed professionally through various programs to increase their personality competence. Regional culture-based personality will better affect students' character formation.

The fourth factor is related to the level of self-efficacy of vocational school teachers. This concept was first introduced by Albert Bandura, a renowned psychologist in the USA. Albert Bandura implemented social learning theory, which is the forerunner of the construction of social cognitive theory as a root of the science of self-efficacy analysis [17]. Self-efficacy is individual complete belief on their professional ability to perform certain tasks successfully. Another definition of selfefficacy is a person's beliefs about their ability to organize and implement whatever measures required to achieve the desired performance [18]. In general, self-efficacy is the belief of individuals in their professional ability to perform certain tasks successfully. Measurement of self-efficacy possessed by someone refers to three dimensions, these are magnitude, generality, and strength. The first dimension is related to the difficulty level of the tasks practically performed by the professionals, starting from the high, medium and low level. Meanwhile the second aspect is related to confidence in one's professional abilities. The last dimension is related to the aspect of power level of confidence in one's professional ability [19]. A Strong belief in the profession beliefs, combined with the mastery of the background of cultural insights social environment and community value system order make professional teachers more qualified.

These four factors are constructed in the commitment structure of professional vocational teachers' ethnopedagogical competences. The concept of education and culture are two sides of the coin, which cannot be separated from each other and from social institutions of society. Their development and changes are life value system than will become the content of knowledge. School education system cannot be separated from the society, because education is the value system of a miniature of people's social system institutions. Each community has different characteristics, patterns, and cultural social value systems. Similarly, learners also have value system background that is different from each other, so teachers' professional attitude will be able to give a correct understanding about the heterogeneity, tolerance and cultural value system that will strengthen the educational value system, even a professional teacher should be an heir to the professional culture when teaching in the classroom [20]. Professional teachers require comprehensive reinforcement on the principles of ethno-pedagogical that would be an investment in the development of the learning process, the transfer of knowledge and values of life. Vocational technology education possess its own pedagogic characteristics because it contains the value system of formation of human 
resources in the form of labors who are skilled, competent, relevant to the industry and understand the social and cultural value systems of the society.

The strength of the local culture in education is often known as ethno-pedagogy which leads to the dimensions of culture-minded teachers. Teachers and learners collaborate to form a social synthesis with a strong emotional commitment, mutual understanding, highly tolerance in the context of learning in the classroom. Cultural power spirit is implied in Japanese education in the form of 'kizuna' and has proved to result in the teaching with the heart, touching with empathy is an instrument of adhesive for the relationship between teachers and learners. Its main objective is to build trust in each other and build emotional commitment, it is even bigger goals is to build the profile of teachers that can become an inspiration and can guide learners to achieve their desires and hopes. Its broader implementation is developed in teacher education in building the capacity of 'kizuna' that is internalized in the teachers' teaching culture [21].

Like 'kizuna', West Java also has a very strong cultural value system crystalized in people's life. This cultural value system was developed in the improvement of vocational teachers' competences, so it can be applied in the classroom. The characteristics of socio-cultural community of West Java are implied in the social interaction of life values and include: pinter (smart), parigel (skilled), silih asih (mutual love), silih asuh (mutual care), silih asah (mutual learning), hurip (healthy), waras (healthy), bener (righteous), bageur (friendly), siger tengah (balanced), teuneung ludeung (courageous), masagi (capable). The value system of the society, if properly adopted for developing the process of the improvement of the teachers' professional competences, will give a multidimensional impact on the educational process. Professional teachers will possess higher capabilities in various dimensions of learning process. Learning will no longer have mechanistic nuance, that is, teacher-students relationship that was limited only in the classroom. Instead, it will form a social community in an order of a complex family. Teachers will give all their capabilities, time and potentials they possess.

\section{METHODS}

Based on the construction of a 'grand theory' in the picture above, a research will be conducted on professional vocational teachers in West Java based on the complex, integrative and multi-dimensional culture of West Java, with the characteristics of the power of Sundanese local ethnic culture. The type of the research conducted is descriptive category through the approach of evaluation of the profiles and characteristics of professional vocational teachers with the expertise on Electrical Engineering in West Java. The population in this study is vocational teachers with the expertise in Electrical Engineering who had obtained the certificate of professional expertise and are located in West Java. Based on the main data on vocational schools, the number of vocational school with the expertise of electrical engineering in West Java is 106 vocational schools, consisting of 30 state schools and 76 private schools. If we assumed that the average number of vocational teachers at each school who had received professional certificates is 9 people, then the population number is 765 . Considering the working background, academic qualifications, professional task performance, the population taken include 94 professional teachers from state vocational schools.

\section{RESULT AND DISCUSSION}

Based on the research that had been conducted on 94 vocational teachers with the expertise on electrical engineering West Java, comprehensive overview was gained about the commitment of the ethno-pedagogical improvement in Table 1. The scope of the research includes the aspect of understanding about ethno-pedagogical concepts, the scope of people's culture, knowledge of comparative culture, extraction of local culture and understanding that education is a cultural process.

TABLE I. MANIFEST VARIABLEL INDICATOR MEASUREMENT

\begin{tabular}{|c|c|c|c|c|}
\hline \multirow[t]{2}{*}{ No } & \multicolumn{4}{|c|}{ Manifest variable } \\
\hline & Description & Achievement & $\%$ & Degree \\
\hline 1 & $\begin{array}{ll}\text { The standpoint of } \\
\text { cultural history of } \\
\text { vocational education }\end{array}$ & 286 & 60,85 & medium \\
\hline 2 & $\begin{array}{ll}\text { Local } & \text { cultural } \\
\text { characteristics }\end{array}$ & 267 & 56,80 & medium \\
\hline 3 & $\begin{array}{l}\text { Understanding of the } \\
\text { industrial revolution }\end{array}$ & 231 & 49,14 & low \\
\hline 4 & Appropriate technology & 343 & 72,97 & high \\
\hline 5 & $\begin{array}{l}\text { Application of art and } \\
\text { culture }\end{array}$ & 253 & 53,82 & medium \\
\hline 6 & Comparison of culture & 236 & 50,21 & medium \\
\hline 7 & $\begin{array}{l}\text { The development of } \\
\text { local cultural value } \\
\text { system }\end{array}$ & 202 & 42,97 & low \\
\hline 8 & $\begin{array}{l}\text { The development of } \\
\text { local cultural value } \\
\text { system Culture }\end{array}$ & 239 & 50,85 & medium \\
\hline 9 & $\begin{array}{l}\text { Education as a cultural } \\
\text { process }\end{array}$ & 282 & 60,00 & medium \\
\hline 10 & $\begin{array}{l}\text { Understanding of ethno- } \\
\text { pedagogy }\end{array}$ & 316 & 67,23 & hight \\
\hline 11 & $\begin{array}{l}\text { Maintenance legacy } \\
\text { culture }\end{array}$ & 301 & 64,04 & medium \\
\hline 12 & Modern and local culture & 215 & 45,74 & low \\
\hline
\end{tabular}

Table 1 shows several dimensions from the implementation of ethno-pedagogy in the context of the development of vocational education conducted on 94 vocational teachers with the expertise in electrical engineering in West Java. The first is related to understanding of professional teachers' perspective on the history and culture of vocational education. The achievement percentage is $60.85 \%$, indicating that professional teachers' understanding of the culture, history and the past development of vocational education has a moderate degree. Vocational teachers lack understanding of dynamic correlation of cultural history on people's skills of ancient times such as hunting, fishing, making war equipment and many other skills such as building houses, woodworking etc. Second, the mastery of original culture characteristics of West Java, that include the nature of kinship, mutual cooperation as well as the culture of mutual love, mutual care, and mutual learning have not seemed to become an important part in the implementation of the competences of professional vocational school teachers. The degree of improvement of professional competences is 
only $56.80 \%$, which is a moderate category. This means professional vocational teachers with the expertise in electrical engineering have no exploit the power of local culture as an integral part in strengthening their professional competences.

The local culture of mutual love, mutual care, and mutual learning should build social relationship in class community with harmonious relationship structure, so that there is a strong emotional tie between teachers and students. Egalitarian relationship between teachers and students that grows properly will give a social space with high level of trust. Teaching competences are no longer about technicalities, but has become supporting instrument in directing students towards hopes and dreams. Meanwhile, the dimension related to the understanding of history and culture of industrial revolution is $49.14 \%$ and the understanding of effective technological utilization is $72.97 \%$, indicating contradictive improvement degree, that is, low and high. The improvement of understanding on industrial revolution of vocational teachers has not been optimal, which is actually a forerunner of the development of vocational education. However, on the other side, it turns out that the improvement of the understanding of the effective technology utilization is relatively high. Vocational schools are already superior in the context of the improvement of professional competences.

The other dimensions such as the application of art and culture, comparative culture, the development of local cultural value system, people's culture, education as a cultural process, the preservation of cultural heritage, the combination of modern and local culture have medium degree, indicating that professional vocational teachers' commitment of the improvement on these dimensions has not been optimal. The improvement of the competence of the application of art and culture as a subsystem of teachers' professional competences in learning has not functioned as it should be. The improvisation of professional vocational teachers in correlating the creation of art and culture with the substance of study filed in the process of learning in the classroom has not internalized. Similarly, the understanding of the improvement of competence on the comparative cultures from several countries has not become an important part of professional vocational teachers. Several developed countries such as USA, European countries and Japan are renowned for having original cultures which become the spirit of educational development. The extreme example of Japanese culture that prioritizes high level of discipline of ancestral culture is known as "sushin" (having high moral standards) and "shitsuke" (disciplined). The understanding of comparative cultures from various countries as an integral part in improving professional competences should be an important value input system on the substance of continuous professional development.

One more dimension that has a high degree is the improvement of the competence of understanding on ethnopedagogy. It turns out that vocational teachers have a relatively high commitment to improve the competence of ethnopedagogy. Professional vocational teachers tried to better understand the concepts, substance and implementations of ethno-pedagogy. The use of the ethno-pedagogical terms without their Indonesian language equivalents becomes a proof of their desires to know ethno-pedagogy more comprehensively in various contexts of vocational educations. The strength of the commitment on the improvement of competence on the dimension of ethno-pedagogy reached $67.23 \%$, but it is still on the level of knowledge and has not become a part in value system of the educational process.

\section{CONCLUSIONS}

Based on the analysis examination above, it can be concluded that:

a. The improvement of professional vocational teacher's competences has not become an integral structure in the constellation of continuous professional development.

b. The commitment on the improvement of professional vocational teachers' competences that include academic, personality, ethno-pedagogy, and self-efficacy competence should be developed in the context of local cultural substance strength.

\section{REFERENCES}

[1] Masriam, Bukit, 2014, Dari Kompetensi menuju Kompetisi, Alpha Beta, Bandung.

[2] Goos, M., Stillman, G., \& Vale, C. 2007, Teaching Secondar y school mathematics. Research and Practice for the 21st century. Sydney: Allen \& Unwin.

[3] Sangra, A.; Gonzalez-Sanmamed, M.; Guitert, M., 2013 "Learning ecologies: Informal professional development opportunities for teachers," Educational Media (ICEM), IEEE 63rd Annual Conference International Council for , vol., no., pp.1,2, 1-4 Oct.

[4] Zabasta, A, Kunicina, N, Zhiravecka, Patlins, Ribickis, 2013, Establishing regional competence centre for life long learning in electrical engineering, Control \& Automation (MED), Mediterranean Conference on , vol., no., pp.578,583, 25-28 June 2013

[5] Jean Claude Vachon and Richard Gagnon, 2002, Teacher Training Vocational Education, Gouvernement du QuébecMinistère de 1.Éducation, 2002.01-01441ISBN: 2-550-39100-4 Legal Deposit.Bibliothèque nationale du Québec.

[6] Ball, D. L. \& Cohen, D. K, 1999, Developing practice, developing practitioners: Toward a practice-based theory of professional education. In G. Sykes and L. Darling-Hammond (Eds.), Teaching as the learning profession:Handbook of policy and practice (pp. 3-32). San Francisco: Jossey Bass.

[7] Lieberman, A. (1994). Teacher development: Commitment and challenge. In P. P. Grimmett \& J. Neufeld (Eds.), Teacher development and the struggle for authenticity:Professional growth and restructuring in the context of change (pp.15-30). New York:Teachers College Press.

[8] Guskey, T.R., 2000, Evaluating Professional Development. Thousand Oaks, CA: Corwin Press.

[9] Cochran-Smith, M., \& Lytle, S. L., 2001, Beyond certainty: Taking an inquiry stance on practice. In A. Lieberman \& L. Miller (Eds.), Teachers caught in the action:Professional development that matters (pp. 45-58) New York: Teachers College Press.

[10] Per Andersson \& Susanne Köpsén, 2014, Continuing professional development of VET teachers : participation in a national initiative in Sweden Linköping University, Høgskolen Oslo og Akkershus 11-13. juni 2014

[11] Sturing, L., Biemans, H., Mulder, M., \& Bruijn, E., 2011, The nature of study programmes in vocational education: Evaluation of the model for comprehensive competence-based vocational education in the Netherlands. Vocations and Learning, 4, 191-210. doi:10.1007/s12186011-9059

[12] Bowden, J. A., \& Masters, G. N., 1993, Implications for higher education of a competency-based approach to education and training. Canberra: Australian Government Publishing Service. 
[13] Arguelles, A., \& Gonczi, A, 2000, Competency based education and training: A world perspective.Balderas, Mexico: Editorial Limusa S.A. de C.V. Grupo Noriego Editores.

[14] Wesselink, R., Biemans, H. J. A., Mulder, M., \& van den Elsen, E. R., 2007, Competence-based VETas seen by Dutch researchers. European Journal of Vocational Training, 40, 38-51.

[15] Smith, E., 2009, Teacher, Instructors and Trainers: An Australian Focus. Maclean, R., Wilson, D. International Handbokof Education forthe Changing World of Work brdidging Academic and Vocating Learning.Germany: UESCO-UNEVOC

[16] Beven, F. , 2009, The Development of Training Modules forInstructor Maclean, R., Wilson, D. International Handbok of Education forthe Changing World of Work brdidging Academic and Vocating Learning.Germany: UESCO-UNEVOC
[17] Lenz, E. R. \& Baggett, L. M.S. (2002). Self Efficacy in Nursing: Research and Measurement Perspectives. NY: Sringer Publishing Company.

[18] Pajares, F. \& Urdan., 2006, Self efficacy beliefs of adolescent. USA: Information age publishing.

[19] Bandura, Albert, 1997, Self-efficacy: The Exercise of Control, New York, USA: W.H. Freeman.

[20] Martinet.at.al, 2001, Teacher Trainining in Vocational Education, Orientation Professional Competencies, (C) Gouvernement du Québec Ministère de l'Éducation, ISBN: 2-550-38257-9 Dépôt légal Bibliothèque nationale du Québec, Kanada.

[21] Shimahara, N. K., Sakai, A. (1998). Teacher internship and the culture of teaching in Japan.In Thomas Rohlen \& Christopher Bjork (Eds)Education and Training in Japan Vol. II. Routledge: London 